\title{
Study on Development of Aviation Logistics Industry in China
}

\author{
Hui Wang \\ Haikou College of Economics, Haikou, Hainan, 570125, China
}

\author{
Keywords: Aviation, Logistics industry, Development study
}

\begin{abstract}
With the constant development and reform of Chinese logistics and trade policies, China has started to develop aviation logistics rapidly. The rapid development of aviation logistics has produced great influence on and brought great challenges to relevant logistics enterprises in China, incurred the improvement of customer demand level and market environment and increased competitors to a certain extent. More challenges and opportunities should be faced. This paper mainly analyzes the development status of Chinese aviation logistics industry, basic concept and features of aviation logistics and suggestions on its future development.
\end{abstract}

\section{Introduction}

Investment subjects of airport construction include local government, civil aviation, local aviation, joint capital of local government and Civil Aviation Administration of China and multiple-party joint capital. Aviation is very important for a city. Each region attaches great importance to airport construction. Therefore, the current stage is an important period for the development of airport logistics. The reform and opening up of China has brought great opportunities and challenges to aviation logistics. During the $8^{\text {th }}$ Five-Year Plan, the construction of 43 airports has been completed gradually. During the $9^{\text {th }}$ Five-Year Plan, the construction of 53 airports has been completed, including 40 in key central cities. There are over 150 airports in China and an aviation network with corresponding intensity has gradually formed.

\section{Development status of aviation logistics industry in China}

In the current stage, the development of aviation logistics in China still remains in traditional cargo handling, processing and storage on the ground and its business is scattered and single. It has a great gap with modern logistics service system and functions and cannot fully meet actual demands of enterprises for logistics development. Currently, domestic aviation logistics cannot provide relatively perfect services with higher requirements and specification such as tracking of cargo on-the-way information and cargo arrival service. Therefore, how to integrate and improve global resources of domestic aviation logistics becomes especially important. The development of aviation logistics should fully accord with the practical situation of airport construction and its development level. It can drive economic development of airport regions. Therefore, it is very important to build airport facilities according to actual demands. According to actual demands of aviation logistics development, there are generally many high-tech products and distribution centers around an airport as high technology is characterized by rapid product updating and high additional value and can fully meet actual demands of aviation logistics transport. Many manufacturers want to set up a certain supply chain system during airport construction as an important basis for the judgment of good investment environment. There are corresponding problems for transnational enterprises in large cities. How to establish high-efficiency and large-scale logistics hub and adapt to logistics and international trade with rapid development becomes an important basis and guarantee of distributors and manufacturers. Many enterprises and cities on the cutting edge of development combine modern logistics with high technology as main economic pillar of future development. It is very important for domestic development of airport construction to establish aviation logistics strategies. 


\section{Operating features of aviation logistics}

Basic concept of aviation logistics. Currently, there are many different means of expression for aviation logistics, which reflect the same connotation. According to relevant standards of Chinese Logistics Terms, aviation logistics can be defined as an entity flow process in which goods are delivered to the place of receipt from the place of supply with air transport as the main mode of transport and transport, handling, storage, packaging, carrying, processing and circulation, distribution and information processing are integrated organically according to actual transport demands and specification ${ }^{[2]}$.

Formation of aviation logistics. Aviation logistics is characterized by fund and time saving, fast air transport, globalization and high efficiency. The optimal price can be found in the airport. Therefore, it is more appropriate to industries with high transport demand and short production cycle which are generally some highly concentrated industries with advanced management and technology, strong concept and intention of supply chain management and social logistics. Aviation enterprises have gradually emerged with the reasonable integration of logistics industry into airfreight during the study and analysis on supply chain management and logistics. Different from common airfreight enterprises, aviation logistics enterprises should organically integrate and unify supply chain management with customer orientation and basic guarantee of information technology and establish "door-to-door" and "one-stop" service under the premise of meeting actual conditions of customers during construction so as to form integrated logistics program, provide corresponding products and raw materials for enterprise development, integrate supply, production, storage, transport and sales organically, establish high-quality and efficient organic and integrated personalized aviation logistics service, guarantee the development and inheritance of aviation logistics and airfreight, integrate airfreight into logistics industry reasonably and then form aviation logistics industry. It will not inundate traditional airfreight completely in the development process. Aviation logistics enterprises will gradually form, which can not only provide basic air transport demands, but also organically integrate logistics enterprises according to their development features and advantages so as to establish business outsourcing relation and become an important component of aviation logistics service mechanism.

Basic features of aviation logistics. Aviation logistics is safe, fast and punctual. Meanwhile, unified rate can be set in different regions and aviation logistics can be established based on different cargos, weights and rates. According to basic features of cargo transportation, it can be divided into featured cargo transportation and common cargo transportation. According to different transport properties, it can include international and domestic aviation logistics. According to actual organizational form, it can include chartered carrier, scheduled carriage, air express, combined transport and consolidation. However, it will be influenced and restricted by space, time, weather, means of transport and environment to a certain extent in the development process. To guarantee smooth aviation logistics, it has more complicated form and operational way compared to other types of logistics. For example, the following five steps are required for door-to-door aviation logistics in the operational process: pick up goods with a truck in the place of dispatch, deliver goods, conduct customs clearance and load goods in the starting position of the air port, transport, conduct customs clearance and unload and release goods in the destination, sign for acceptance of goods by the consignee. The most important thing in the process above is information flow. To guarantee safe, fast and punctual aviation logistics, it is necessary to guarantee aviation logistics import data of the process. First, pick up goods. After receiving corresponding instruction sent by domestic aviation logistics enterprises, overseas aviation logistics enterprises should contact with the consigner in time and guarantee goods delivery in time. The consignor should make preparations for transportation according to relevant instruction and standard of actual transport demands and overseas aviation enterprises should check goods carefully and pick up them reasonably. Second, prenotice. Overseas aviation logistics enterprises should handle relevant formalities in time after the receipt of goods and customs clearance according to detailed demands of actual reservation of goods and meanwhile load goods based on the scheduled flight of actual reservation and send prenotice to domestic logistics center, consignor and consignee ${ }^{[3]}$.Third, transport information. In the transport process, overseas 
aviation logistics enterprises should adapt to record relevant data of goods in time and send them to consignor, consignee and domestic aviation logistics enterprises in time. The information includes the time of arrival, departure time of flight and accompanied commercial papers etc. Domestic aviation logistics enterprises should communicate with consignor and consignee in time, organize documents required for customs clearance and get ready for customs clearance at any time. Forth, arrival notice. After the receipt of goods, domestic aviation logistics enterprises should contact with consignor, consignee and overseas enterprises and arrange and handle customs clearance in time. Fifth, delivery goods. After the release of goods by customs, domestic aviation logistics enterprises should contact with consignee for the receipt of goods in the specified location in time. According to the process above, the center of management in the transport process is aviation logistics enterprises which play a vital role in transportation organization. The opposite process of import process is export process. Import and export process is basically similar to domestic process.

\section{Suggestions on development of aviation logistics in China}

Strengthen supervision. Aviation logistics enterprises with certain marketing mode should be established in the development process. In terms of the development pattern of domestic aviation logistics in the current stage, there is a problem of weak marketing concept. Domestic aviation logistics enterprises should develop into marketing enterprises from original operational enterprises. However, it is most important for enterprises to establish a service awareness and concept based on customer demands and market development for the purpose of transportation. Patterns that can meet actual demands of market development and customers are right.

Integrate enterprise resources. Enterprise resources should be integrated reasonably in the development process. Due to constant development and the expansion of scale of aviation logistics enterprises, not only market efficiency but also organic integration and management of logistics resources are required. Rational allocation and integration of resources can reduce enterprise development costs to a certain extent and obtain corresponding benefits. In the current stage, domestic aviation logistics enterprises generally have the problem of failure to integrate resources rationally. Due to the lack of rational overall consciousness during internal and external market competitions among enterprises, especially branch companies of enterprises, different departments and branch companies have cliquism, thus causing excessive consumption of resources of the whole enterprise. To achieve stable and long-term development, enterprises should establish development objectives according with domestic development situation and world development direction. Domestic aviation logistics enterprises in China have developed relatively late. Though there is a relatively complete logistics network, they have a problem of the lack of overseas network when facing the global market. Therefore, domestic aviation logistics network cannot develop comprehensively ${ }^{[4]}$.

Improve cooperation and coordination with customs and increase efficiency of customs clearance. The guarantee and basis of promoting the development of domestic and international aviation logistics enterprises are simple supervision method, high efficiency of customs clearance and positive customs policies. Examination units related to customs section should develop and adapt to requirements of the times and innovate system, theory, science and technology constantly so as to establish a modern management mode, reform the operational mode of customs constantly and establish and improve automated enforcement system of customs. In addition, relevant management department should increase the input of funds and manpower and contact and cooperate in time so as to find deficiencies and problems in the transport process. It is required to plan and achieve objectives in logistics transportation gradually with advanced management mode, fully understand and master bonded policies, establish bonded warehouse meeting actual specification and demands around the airport, guarantee the provision of one-stop service and epaper for enterprises, design a relatively rational process to guarantee the improvement and realization of customs cooperation objectives and meanwhile establish logistics network and customs contact platform so as to achieve the purpose of online exchange, transmission and processing and increase the efficiency to a certain extent. 
Establish and improve flexible price system. In the process of goods transport, a compensation and remuneration of customers for transport service is actually freight rates of air cargo. Transport price is highly related to market development and economic benefit. Different forms of transport have different costs. In terms of multi-connected transport form, how to establish a form of transport with reasonable price becomes very important. The single use of the same transport mode without correct analysis and consideration of price level will cause unreasonable allocation of logistics resources to a certain extent and the occurrence of under-utilization or over-use of infrastructure. Freight rates should meet actual demands under multi-connected development mode. Freight rates of reasonable ratio should be established and prices of different modes of transport from the same starting point should be compared. Therefore, transport price should be adjusted reasonably according to the practical situation of market price fluctuation so as to guarantee competitive advantages of enterprises. It plays a vital role in the improvement of economic benefit and overall service quality. Relevant departments should control the lowest and highest transport price reasonably, guarantee reasonable and appropriate competition and avoid lack of competition or excessive competition and meanwhile establish an external environment according with the competition mechanism without damaging interests of competition parties. Due to cargo transportation time with different sensitivity, it is necessary to use a flexible price mode with multiple prices reasonably, refine rate class constantly and guarantee a supply-demand relation meeting the specification. Meanwhile, differences of cargo transportation at different prices can be reflected. Meanwhile, freight rates should be implemented flexibly and reasonably according to different seasons and routes ${ }^{[5]}$.

\section{Conclusion}

In conclusion, logistics industry is a new industry in the world. Its construction is not perfect in China. Aviation logistics is just in the initial development stage and gradually becomes a research emphasis of relevant scholars and experts. With constant development of and study on freight logistics and aviation, this paper focuses on analyzing the development status and features of Chinese aviation logistics and suggestions so as to promote the rapid development of aviation logistics and economic progress of China.

\section{References}

[1] Wang Chen. Study on Interactive Relation between Guangxi Aviation Logistics and Regional Economic Development - from Perspective of System Dynamics. Guangxi Social Science, 2010(10):64-67.

[2] He Weihua. Develop International Aviation Logistics and Promote Construction of Comprehensive Experimental Area of Economy in Zhengzhou Air Harbor. Journal of Huanghe Science and Technology University, 2014,16(3):35-38.

[3] Pan Daoyuan, Luo Qinghe. Study on Efficiency of Aviation Logistics Chain from Perspective of Airport Goods Station. Logistics Science and Technology, 2014,37(9):142-145.

[4] Zhou Yang. Countermeasures for Development of Aviation Logistics in Economic Experimental Area in Zhengzhou Air Harbor. Logistics Engineering and Management, 2014(5):23-25.

[5] Gao Renwen. Exploration and Analysis on Development Prospect of Aviation Logistics under E-commerce Background. China Business and Trade, 2011(15):156-157. 